\title{
NEW RECORDS OF TRICHOPTERA IN REFERENCE MEDITERRANEAN-CLIMATE RIVERS OF THE IBERIAN PENINSULA AND NORTH OF AFRICA: TAXONOMICAL, FAUNISTICAL AND ECOLOGICAL ASPECTS
}

\author{
N. Bonada*, C. Zamora-Muñoz**, M. El Alami***, \\ C. Múrria* \& N. Prat*
}

\begin{abstract}
Trichoptera is a very rich order in the Western Mediterranean, but knowledge of caddisflies in the Iberian Peninsula and northern Africa is still not complete. We present records of caddisflies collected in 114 sites of the Mediterranean climate region of the Iberian Peninsula and the western Rif. We also provide notes on ecological aspects and taxonomical remarks on some species. A total of 86 species were identified and 8 species extended their distribution range. Considering the four differentiated geological regions in the western Mediterranean Basin during the Tertiary, 60 species were collected in the Iberian plate region, 29 in the Transition, 30 in the Betic and 18 in the Rif. Local richness was not significantly different between the four regions but significant differences were found among several river ecotypes within regions. Temporary sites had lower local richness than other ecotypes in all regions except in the Rif, whereas headwaters had similar richness in any region regardless of their geology. The Rif region had the lowest Trichoptera richness, which is not only the result of the scarcity of faunistic studies in the area but also of the high frequency of temporary rivers and the isolation of the area. Our results suggest that conservation measures addressed to preserve the biodiversity of the Western Mediterranean should be enforced, especially in the Rif region.
\end{abstract}

Key words: Trichoptera, Mediterranean rivers, Iberian Peninsula, Morocco, Faunistic, Taxonomy, Ecology.

\section{RESUMEN}

\section{Nuevos datos de tricópteros en ríos de referencia de clima mediterráneo en la Península Ibérica y norte de África: aspectos taxonómicos, faunísticos y ecológicos}

El orden Trichoptera es rico en especies en la zona del Mediterráneo Occidental, pero el conocimiento de este grupo en la Península Ibérica y el norte de África resta aún de ser completo. Presentamos datos de tricópteros recolectados en 114 localidades de la región Mediterránea de la Península Ibérica y del Rif occidental. Además, proporcionamos datos sobre la ecología de algunas especies así como notas taxonómicas. Se identificaron un total de 86 especies y el rango de distribución aumentó para 8 de ellas.

* Department of Ecology, University of Barcelona, Diagonal, 645. E-08028 Barcelona (Spain)

** Department of Animal Biology, University of Granada, Faculty of Science, Campus Universitario de Fuentenueva. E-18071 Granada (Spain)

*** Department of Biology, University Abdelmalek Essâadi, Faculty of Science Tétouan B.P. 2121. Tétouan (Morocco) 
Sesenta especies se recolectaron en la región de la placa Ibérica, 29 en la de Transición, 30 en la Bética y 18 en el Rif, las cuatro regiones geológicas diferenciadas durante el Terciario en el Mediterráneo Occidental. La riqueza local no fue significativamente diferente entre regiones geológicas, pero sí entre varios ecotipos fluviales. Los tramos temporales presentaron una riqueza local menor que los demás ecotipos, excepto en el Rif, mientras que las cabeceras presentaban una riqueza similar en cada región independientemente de su geología. Globalmente el Rif presentó una menor riqueza de tricópteros, lo que se explica no sólo por la escasez de estudios faunísticos en la zona sino también por la elevada frecuencia de ríos temporales y su aislamiento geográfico. Nuestros resultados sugieren que en la zona del Mediterráneo Occidental se deben de llevar a cabo medidas de conservación urgentes para preservar su biodiversidad, especialmente en la región del Rif.

Palabras clave: Trichoptera, ríos Mediterráneos, Península Ibérica, Marruecos, Faunística, Taxonomía, Ecología.

\section{Introduction}

The Mediterranean Basin has been considered a hotspot of biodiversity, at least when looking at plants and vertebrates (Myers et al., 2000). Insects are also diverse in the area especially when considering the reduced dimensions of the emerged land (Balleto \& Casale, 1989). In particular, the western Mediterranean, and specially the south of the Iberian Peninsula and the north of Morocco (i.e. Betic-Rif ranges), is one of the two main centres of biodiversity within the Mediterranean Basin (Médail \& Quézel, 1997). Likewise, Trichoptera is a very rich order in the Western Mediterranean, with about 390 species in the Iberian Peninsula (González, 2007) and 72 in Morocco (Dakki, 1980). In spite of having a high caddisfly richness, the knowledge of caddisflies in the Iberian Peninsula and north of Africa is still incomplete, new species are still recorded and many larval stages are not yet described (e.g. González \& Ruiz, 2001; Zamora-Muñoz et al., 2002, 2006). Consequently, general studies providing information about caddisflies are required in both areas to have a consistent taxonomy of the group which will help to carry out proper ecological studies or to promote specific conservation measures.

Thus, our main aim was to complement the existing information (e.g. Dakki, 1980; González et al., 1992; Vieira-Lanero, 2000; Ruiz et al., 2001; Bonada et al., 2004b) with new records. The study area broadly corresponds to that studied in Bonada et al. (2004b) but with new sites and basins, including those found in the western Rif. The caddisfly records presented follow the taxonomical classification described in Wiggins (1996) and are updated using Fauna Iberica (www.fauna-iberica.mncn.csic.es) and Fauna Europaea (www.faunaeur.org) web services. In addition, we follow the traditional species terminology and escape from recent synonyms without a consistent study of the species implied (Botosaneanu, in letter to C. Zamora-Muñoz, 2005). In some cases, we also provide taxonomical notes. Notes on ecological aspects of the species not already included in Bonada et al. (2004b) are given by using information compiled by the Guadalmed project (see www.ecostrimed.net) or by using references provided in Table 1.

Several authors have suggested that a mixture of complex past historical processes occurring during the Tertiary and Quaternary with current heterogeneous environmental conditions are responsible for the high biodiversity found in the Mediterranean Basin (Balleto \& Casale, 1989; Hewitt, 2004; Bonada et al., 2005). Among historical factors, those that occurred during the Tertiary in the western Mediterranean Basin resulted in four differentiated geological regions: Iberian Plate, Transition, Betic and Rif. Among ecological factors, basin geology, river zonation and seasonal variability are the most relevant to understand caddisfly distribution (Bonada et al., 2005). Both groups of factors have implications on regional richness which in turn influences local richness (Vinson \& Hawkins, 2003). We will analyze Trichoptera from these geological regions in terms of regional (i.e. richness in each geological region) and local richness (i.e. richness in each site). Given that basin geology and river zonation are the main environmental factors constraining caddisflies 
(Bonada et al., 2005), we will analyze local caddisfly richness between five river ecotypes based on these factors and described by SánchezMontoya et al. (2007) within geological regions: (1) temporary streams, (2) evaporite calcareous streams at medium altitude, (3) siliceous headwaters at high altitude, (4) calcareous headwaters at medium and high altitude and (5) large watercourses. By examining this, we will explore how main historical and environmental factors constrain local richness at two nested spatial scales (i.e. geological region and ecotype).

\section{Material and methods}

We collected Trichoptera specimens from 114 sites belonging to 28 basins. All sites were considered as reference regarding their ecological quality (Bonada et al., 2004a) and located in different river sections (i.e. headwaters, midstreams and lowland reaches) with different basin geology (i.e. calcareous, siliceous or sedimentary) and at different altitudes (from 20 to 1940 m.a.s.l., Appendix). Our study was focused within the limits of the Mediterranean climate established by Köppen (1931) and covered a sampled area of 70854.12 $\mathrm{km}^{2}$, from the northeast of the Iberian Peninsula to the western Rif zone in Morocco (Fig. 1). The sampled area was divided into 4 different geological regions: the Iberian Plate (42 sites), the Transition zone ( 9 sites), the Betic (43 sites) and the Rif zones (20 sites). The Iberian Plate comprises the area of the Iberian Peninsula which includes the Hesperic Massif (west of the Iberian Peninsula which originated in the hercinic orogeny during the Carboniferous), the Iberian Ranges (east of the Hesperic Massif with a hercinic base and a sedimentary cover) and the Catalan Ranges (northeast of the Hesperic Massif with a hercinic and alpine orogeny origin and a sedimentary cover). The Transition zone is equivalent to the Prebetic area, located in the external zone of the Betic Ranges and originated, before the collision of the Betic-Rif microplate, by marine deposits or terrestrial sediments from the Iberian Plate. The Betic zone encloses the Internal Zone of the Betic Ranges (also called Betic s.s.), which was part of the Betic-Rif microplate, and the flychs deposits, coming from eastern areas and reached the Strait of Gibraltar with the migration of the Betic-Rif microplate (Sanz de Galdeano \& Vera, 1991). Likewise, the Rif zone comprises the Internal zone and the flychs deposits of the Rif Ranges (Fig. 1).
In each site, we sampled all available habitats with a kick net of 250-300 $\mu \mathrm{m}$ mesh size depending on the survey, until no new caddisfly families were observed in the field. Samples were preserved in formalin $(4 \%)$ or alcohol $(96 \%)$ and identified to the species level in the laboratory. In addition, lastinstar larvae and pupa were collected in the field and reared in the laboratory to obtain adults for ensuring larval identifications (for the method used see Bonada et al., 2004b). When possible, adults were also obtained in the field by sweeping riparian vegetation with an entomological net or by using a UV-light trap.

Local richness referred to the number of species collected at each site. In order to check local richness of caddisflies between ecotypes within geological regions we performed a nested ANOVA. Residuals were checked for normality and homogeneity of variances using Shapiro-Wilk and Bartlett tests, respectively. The nested design included 2 fixed factors nested as follows: ecotype nested to geological region. Although nested ANOVA designs usually use random nested factors, fixed factors can also be used (Quinn \& Keough, 2002). As mentioned, the geological region factor includes: Iberian Plate, Transition, Betic and Rif. Regarding ecotypes, we used those developed for Mediterranean Basin rivers in Sánchez-Montoya et al. (2007): (1) temporary streams, (2) evaporite calcareous streams at medium altitude, (3) siliceous headwaters at high altitude, (4) calcareous headwaters at medium and high altitude and (5) large watercourses (Appendix). These statistical analyses were performed using the $\mathrm{R}$ freeware (http://www.r-project.org/).

\section{Results}

A total of 4041 larvae, 25 pupae and 131 adults were collected in the sampled area. Most of them were identified at species level, resulting in 86 different species. For each species, information of number of larva (L), pupae $(\mathrm{P})$ and adults $\left(\mathrm{O}^{7}\right.$ and O ) collected are provided. For mature pupae and adults, the months of capture are presented in brackets after the locality. When the identity of the identification was not clear, a question mark (?) is added before some sampling sites or number of specimens. Sites are arranged by latitude of the whole basin (Fig. 1) and information about geographical position and general environmental characteristics of each locality is found in the Appendix. 


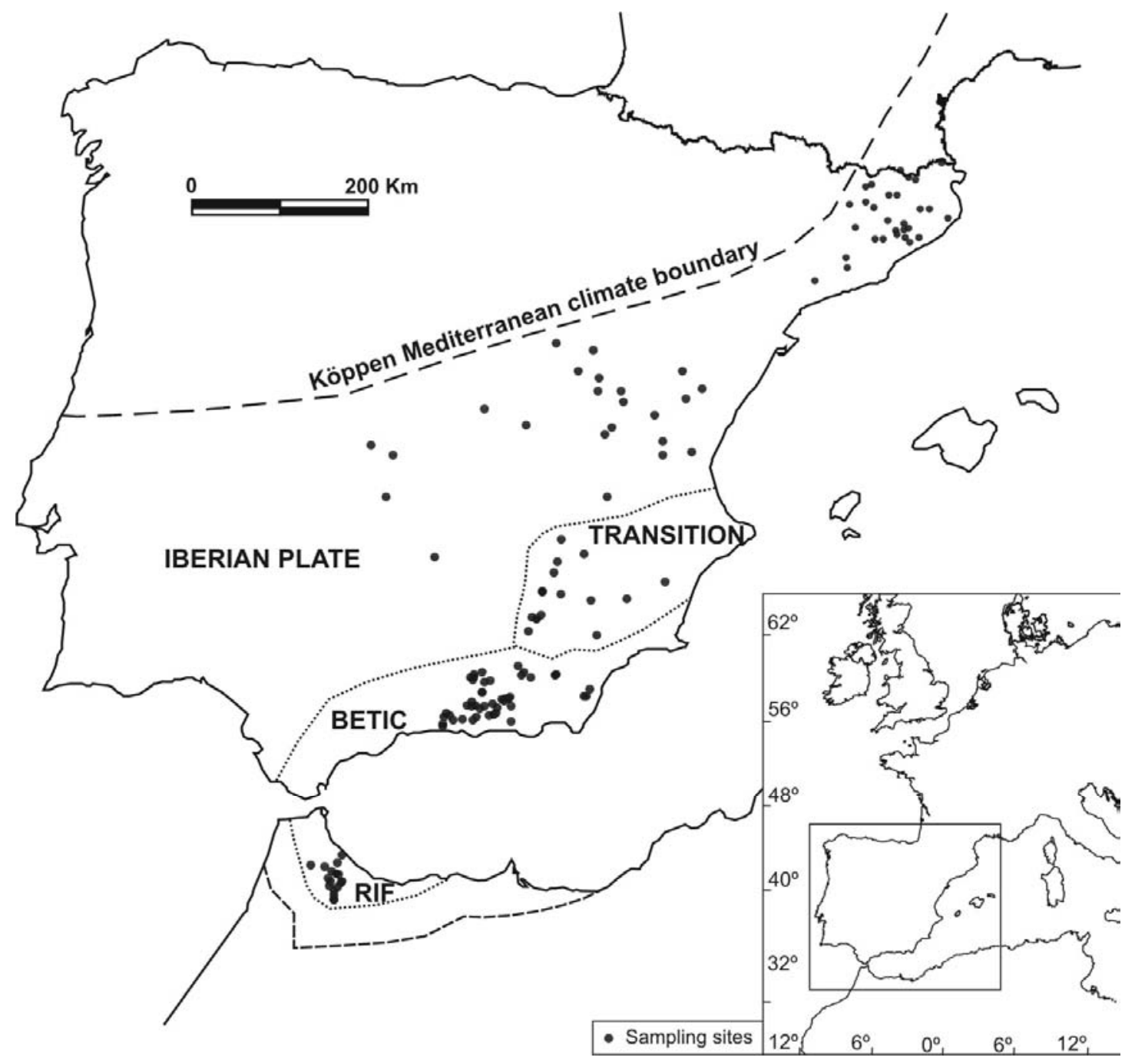

Fig. 1.- Site location and sampling area grouped by geological regions: Iberian Plate, Transitional, Betic and Rif zones. The boundary of the Mediterranean climate according to Köppen (1931) is also shown. See Appendix for detailed information on site location.

Fig. 1.- Localización de las estaciones de muestreo y de la zona muestreada agrupadas por regiones geológicas: Placa Ibérica, Transición, Béticas y Rif. Se muestra también el límite del clima Mediterráneo según Köppen (1931). Ver el Apéndice para obtener información detallada sobre la localización de las estaciones.

\section{Faunistic list}

Suborder SPICIPALPIA

Family RHYACOPHILIDAE Stephens, 1836

Subfamily Rhyacophilinae Stephens, 1836

Rhyacophila Pictet, 1834

Rhyacophila dorsalis (Curtis, 1834)

MATERIAL STUDIED: 18L. Fluvià: H18; Ter: H27, H29; Llobregat: H22, H32; Tajo: H9, H12
Rhyacophila evoluta McLachlan, 1879

MATERIAL STUDIED: 16L. Ter: H24, H25

Rhyacophila fasciata Hagen, 1859

MATERIAL STUDIED: ?3L. Fluvià: H18, H19

Larvae found corresponded to this species but there is controversy about the presence of this species in the Iberian Peninsula (see Bonada et al., 2004b). 
Rhyacophila fonticola Giudicelli \& Dakki, 1984

MATERIAL STUDIED: 10L. Martil: R14; Laou: R3, R4, R8

See comments for Rhyacophila munda.

Rhyacophila meridionalis E. Pictet, 1865

MATERIAL STUdied: 30L. Tordera: H14; Tajo: H5; Júcar: H4; Guadiana: H11; Segura: T1; Guadiana Menor: T5; Adra: B1, B2, B3

Rhyacophila munda McLachlan, 1862

MATERIAL STUDIED: 56L, 1P. Tajo: H8; Júcar: H4, H13, T3; Guadiana: H1; Segura: T4; Guadalquivir: H6; Guadiana Menor: ?B27, ?B31, ?B32, T6, ?T8; Genil: B10, ?B12, ?B15, B19, ?B19; Guadalfeo: B24; Chillar: B7; Verde: B35; Laou: R1, R2, R7, R8 (1Pơ': V-2005); R13; Sebou: R18; Adelmane: R15

Larvae found in some sampled sites of Genil and Guadiana Menor basins, marked with "?", were provisionally assigned to this species, but they presented an atypical dark coloration in the head. The recent description of the larva of $R$. fonticola (Vieira-Lanero et al., 2008) make us think that they could belong to this species. Adult material should be collected to clarify the identity of these specimens.

\section{Rhyacophila nevada Schmid, 1952}

Material STUdied: 19L, 22A. Guadiana Menor: T9; Genil: B9, B11 (150"0', 7 우 ㅇ: VIII-2007); Guadalfeo: B22, B26

Although Malicky (2002; 2005b) considered this species as a subspecies of $R$. dorsalis, we believe that it should be kept as a distinct species because of larval morphology and ecological requirements (see more details in Bonada et al., 2004b).

\section{Rhyacophila occidentalis McLachlan, 1879}

Material STUdied: 12L, 1A. Genil: B9, B11 (1 $0^{7}$ : VIII-2007); Guadalfeo: B20, B23

With the adults collected in the Genil Basin, specimens from other sites in Sierra Nevada mountains (from Adra and Guadalfeo basins), identified as $R$. cf. occidentalis in Bonada et al. (2004b), correspond, probably, to this species.

Rhyacophila rupta McLachlan, 1879

MATERIAL STUDIED: 1L. Llobregat: H32

\section{Rhyacophila cf. tristis Pictet, 1834}

Material Studied: 9L. Ter: H24, H25, H26; Llobregat: H23

See Bonada et al. (2004b) for comments on the difficulty of identifying the tristis group.
Family GLOSSOSOMATIDAE Wallengren, 1891

Subfamily Agapetinae Martynov, 1913

Agapetus Curtis, 1834

As reported before (Bonada et al. 2004b) this genus contains one species with undescribed larvae present in our sampled area (Agapetus theischingeri Malicky, 1980). In addition, most of the morphological characters used to distinguish species use lateral and ventral abdominal setae patterns (e.g. see Pitsch, 1993). This may yield misidentifications because these setae may be broken or not clearly visible. For example, two specimens found in Tajo Basin (H5) had only one lateral seta in the first abdominal segment and very few dorsal setae in the ninth abdominal sclerite. Given this difficulty, here we only present specimens with larvae that fit in the known species and from sites where pupae or adults have been collected previously (Bonada et al., 2004b).

Agapetus fuscipes Curtis, 1834

Material STUdied: 114L, 2P. Ter: H25; Guadiana: H1; Guadiana Menor: B28 (1Pơ : IV-2003); Genil: B14 (1P 9 : I2004); Adra: B2, B4

Agapetus delicatulus McLachlan, 1884

Material STUDIED: 2L. Ter: H25

Agapetus beredensis Dakki \& Malicky, 1980

Material StUdied: 16L, 1P. Laou: R13; Adelmane: R15 (1PO': VI-2003), R16

Agapetus incertulus McLachlan, 1884

Material STUdied: 33L, 1P. Laou: R13 (1Po': V-2005). Genil: B10, B12, B13, B15, B18, B19; Verde: B35; Martil: R14; Adelmane: R15, R16

Ruiz et al. (2004) reported that larva of $A$. incertulus does not have ventral setae in the sixth and seventh segments. Although most of our specimens followed this character (as well as the others characteristics of this species), some specimens in B13 and B15 had ventral setae in at least one of these segments.

Agapetus nimbulus McLachlan, 1879

Material Studied: 29L, 3P, 1A. Guadiana Menor: B29, T8 (1P O', 1P o : IV-2003; 1P ○", $\left.10^{7}: \mathrm{X}-2005\right)$

This species was recently cited from the Iberian Peninsula (Zamora-Muñoz et al., 2006). The larvae are similar to those of Agapetus segovicus Schmid, 1952. Thus, the intention of building a key with the described species of the Iberian Peninsula was resulted unsuccessful, at least with the characters used until now for the step-keys.

\section{Synagapetus McLachlan, 1879}

Nineteen larvae of this genus have been found in Ter (H17 and H25), Tordera (H14) and Segura (T2 and T4) 
basins. Given the difficulties in the larva taxonomy we did not reach to species level for this genus.

Subfamily Glossosomatinae Wallengren, 1891

Glossosoma Curtis, 1834

Glossosoma boltoni Curtis, 1834

MATERIAL STUDIED: 28L, 1P. Ter: ?H24, ?H25; Genil: B9, B26 (1 PO': XI-2005)

By distribution (northern basins of the Iberian Peninsula), specimens from the Ter Basin could also belong to Glossosoma spoliatum McLachlan, 1897, whose larva has not been described yet (Bonada et al., 2004b).

Family HYDROPTILIDAE Stephens, 1836

Subfamily Hydroptilinae Stephens, 1836

Tribe Hydroptilini Stephens, 1836

Allotrichia McLachlan, 1880

Allotrichia pallicornis (Eaton, 1873)

MATERIAL STUDIED: 6L. Fluvià: H20; Guadiana: H3

Hydroptila Dalman, 1819

We collected 178 larva specimens belonging to this genus but because many immature forms of Iberian species remain undescribed, we only present here results from sites where pupa or adults of the species were found.

Hydroptila gr. sparsa Curtis, 1834

Material studied: 21L, 1P. Guadalfeo: B25 (1PM: IV-2003)

Hydroptila vectis Curtis, 1834

Material StUdied: 14L, 4P, 1A. Guadiana Menor: T9 (1Po", $1 \mathrm{P}$ \% : VII-2003); Genil: B14 (1 ㅇ : IV-2003); Guadalfeo: B22 (2P 우 우: VII-2003)

\section{Oxyethira Eaton, 1876}

Three specimens from this genus have been found in Francolí (H35), Júcar (T3) and Guadalfeo (B25) basins. Given the difficulties of identifying larvae, we did not reach species level.

Tribe Orthotrichiini Nielsen, 1948

\section{Ithytrichia Eaton, 1873}

Three specimens of this genus (not identifiable at species level because of the scarcity of published information on larval morphology, Vieira-Lanero, 2000) were found in the Guadiana Basin (H11).

Orthotrichia Eaton, 1873

Orthotrichia angustella (McLachlan, 1865)

Material STUdiED: 8L. Fluvià: H20; Calonge: H35; Tordera: H14
Suborder ANNULIPALPIA

Superfamily PHILOPOTAMOIDEA Stephens, 1829

Family PHILOPOTAMIDAE Stephens, 1836

Subfamily Philopotaminae Stephens, 1836

Philopotamus Stephens, 1829

Philopotamus montanus (Donovan. 1813)

Material studied: 46L, 1P, 10A. Muga: H33; Fluvià: H18; Ter: H17, H24, H25, H26; Tordera: H14, H15, H16; Guadiana Menor: B27 (1 $\sigma^{x}$ : IV-2003; $10^{7}:$ VII-2003; 2 우 ㅇ: X-2005), B29; Genil: B9 (1 $0^{x}:$ X-2005), B19 (1 ㅇ : VII-2003); Adra: B1 (2 $\sigma^{7} \sigma^{7}$ : VII-2003), B3 (1 $\sigma^{7}:$ III-2003), B4, B5; Guadalfeo: B23 (1PO': V-2003; $10^{7}:$ XI-2005); Chillar: B6

\section{Wormaldia McLachlan, 1865}

We found 115 larvae of this genus in Muga (H33), Ter (H28), Tordera (H14, H15 and H16), Llobregat (H23), Júcar (T3), Guadiana (H1), Guadiana Menor (B30, B33, B35), Genil (B15), Guadalfeo (B25), Chillar (B7) and Laou (R13) basins. Only one female was found in Genil Basin (B19) in July-2003. Given that no males were found, it was not possible to reach the species level.

Subfamily Chimarrinae Rambur, 1842

Chimarra Stephens, 1829

Chimarra marginata (Linnaeus, 1767)

MATERIAL STUdiEd: 46L. Muga: H33; Fluvià: H20; Llobregat: H22, H23; Francolí: H35; Ebre: H37; Tajo: H5, H8, H9; Júcar: H7; Segura: T1; Guadalquivir: H38; Jara: B36; Guadalfeo: B37; Martil: R20.

Superfamily HYDROPSYCHOIDEA Curtis, 1835 Family HYDROPSYCHIDAE Curtis, 1835

Hydropsyche Pictet, 1834

Hydropsyche cf. angustipennis (Curtis, 1834)

MATERIAL STUDIED: 1L. Ter: H26

Although some larva specimens from northern basins have been recently assigned to this species (Valladolid et $a l ., 2007)$, adult records in the Iberian Peninsula are not known despite being recorded in the Balearic Islands (González et al., 1992). Our specimen clearly shows the distinctive features of this species (Neu \& Tobias, 2003) but adult material should be collected to confirm its presence in the area.

Hydropsyche brevis Mosely, 1930

Material STUdied: 4L. Tajo: H5; Júcar: H7; Segura: T4

Hydropsyche bulbifera McLahlan, 1878

MATERIAL STUDIED: 5L. Fluvià: H18, H20 
Hydropsyche dinarica Marinkovic-Gospodnetic, 1979

Material STUdiEd: 56L. Ter: H17, H24, H25

Hydropsyche exocellata Duföur, 1841

Material STUDIED: 11L. Fluvià: H20, Tajo: H10; Segura: T1

Hydropsyche fezana Navás, 1935

MATERIAL STUDIED: 314L. Laou: R2, R3, R4, R5, R8, R12, R13; Adelmane: R15, R16; Sebou: R17, R18

Hydropsyche fontinalis Zamora-Muñoz \& González, 2002 MATERIAL STUdiEd: 1L. Guadiana Menor: T8

\section{Hydropsyche infernalis Schmid, 1952}

Material studied: 110L, 1P, 5A. Guadiana Menor: B28, B29, B32, B33, B40 (10": X-1996; $20^{7} 0^{7}$ : VI-1997); Genil: B10,

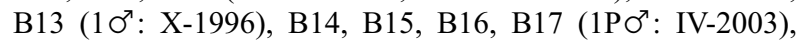
B19, B43 (1 $\sigma^{7}$ : VIII-2007); Adra: B4, B5; Guadalfeo: B24, B25; Chillar: B6, B7; Verde: B35

\section{Hydropsyche instabilis (Curtis, 1834)}

MATERIAL STUdiED: 92L, 58A. Fluvià: H18, H19; Tordera: H14; Llobregat: H22; Francolí: H35; Tajo: H5; Guadiana Menor: B31, B32, T9; Genil: B9, B11 (39070': VIII-2007), ?B16, ?B17, B19, B43 (19070': VIII-2007); Adra: B1, B2, B3, B4; Guadalfeo: B20, B22, B23, B26

\section{Hydropsyche gr. instabilis}

MATERIAL STUDIED: 71L. Ter: H28; Llobregat: H23, H32; Foix: H31; Francolí: H35

This species corresponds to the same Hydropsyche gr. instabilis in Bonada et al. (2004b), potentially considered as a new species by larval and male pupa morphology. Recently, molecular analysis using portions of COI gene have revealed that individuals with this morphology constitute a single group that is different from other species within the instabilis group, supporting the idea that it should be considered as a new species (Múrria, unpubl. data). Adult material is however needed to formally describe this species using morphological characters.

Hydropsyche lobata McLachlan, 1884

Material Studied: 81L. Guadiana: H3; Laou: R6, R7, R9, R10, R11, R12

Hydropsyche maroccana Navás, 1935

Material StUdied: 152L, 1A. Laou: R6, R9, R11 (10': V2005), R13

\section{Hydropsyche gr. pellucidula}

MATERIAL STUdiED: 349L. Fluvià: H18, H19; Llobregat: H22, H32; Francolí: H35; Tajo: H8, H9, H10; Guadiana: H11;
Segura: T1; Guadiana Menor: T9; Genil: B18; Guadalfeo: B21; Laou: R1, R6, R7, R9, R10, R11, R12

Given the difficulties of identifying larvae of Hydropsyche iberomaroccana González \& Malicky, 1999, Hydropsyche incognita Pitsch, 1993 and Hydropsyche punica Malicky, 1981 (Zamora-Muñoz et al., 1995; González \& Malicky, 1999), we have grouped all individuals under the pellucidula group. H. incognita has a widespread distribution in Central Europe and in the Iberian Peninsula (Bonada et al., 2004b). However, $H$. iberomaroccana has been recorded in southern Iberian basins and in Morocco (e.g. González \& Malicky, 1999; Bonada et al., 2004b), whereas H. punica has been cited only from northern Africa (Malicky \& Lounaci, 1987; Kumanski, 2006).

Hydropsyche siltalai Döhler, 1963

MATERIAL STUdiEd: 123L. Muga: H33; Fluvià: H18, H19; Ter: H26, H27, H29; Tordera: H14, H16; Tajo: H12; Júcar: T3; Guadiana: H1; Segura: T2, T4; Guadalquivir: H6

Hydropsyche teruela Malicky, 1980

MATERIAL STUDIED: 2L. Segura: T1

Hydropsyche tibialis McLachlan, 1884

Material STUdied: 1L. Adra: B3

Cheumatopsyche Wallengren, 1891

Cheumatopsyche atlantis (Navás, 1930)

MATERIAL STUDIED: 2L. Laou: R7

Malicky (2005b) has considered this species as a synonym of Cheumatopsyche lepida (Pictet, 1834). The study of the larvae collected showed some differences with this species: the hairy areas were less conspicuous than in C. lepida and mostly limited to the anterior margin of the pronotum. We consider, thus, that $C$. atlantis is different from $C$. lepida, but more individuals need to be collected to ensure that $C$. atlantis is a good species.

Cheumatopsyche lepida (Pictet, 1834)

MATERIAL STUDIED: 79L. Fluvià: H20; Ter: H29; Francolí: H35; Júcar: $\mathrm{H7}$

Family PSYCHOMYIIDAE Walker, 1852

Subfamily Psychomyiinae Walker, 1852

Psychomyia Latreille, 1829

Psychomyia pusilla (Fabricius, 1781)

Material StUdied: 45L, 5P. Muga: H33; Fluvià: H18; Ter: H27, H29; Francolí: H35; Tajo: H10; Segura: T1; Laou: R11 (4PƠণ', 1P \& : V-2005), R12 
Lype McLachlan, 1878

Lype phaeopa Stephens, 1836

MATERIAL Studied: 1L. Muga: H33

Metalype Klapálek, 1898

Metalype fragilis (Pictet, 1834)

Material STUDIED: 3L. Llobregat: H22; Tajo: H5

This species has been considered as Psychomyia fragilis by Malicky (2005b).

Tinodes Curtis, 1834

As pointed out in Bonada et al. (2004b) several species of this genus present in the area of study are not described and records presented here should be confirmed, except in cases where adults are found.

Tinodes cf. assimilis McLachlan, 1865

Material Studied: 24L. Júcar: T3; Genil: B12, B13, B15, B18; Adra: B4; Verde: B35

The presence of this species in Guadalfeo and Guadiana Menor Basins has been confirmed by adult collection in previous studies (Zamora-Muñoz, unpubl. data).

Tinodes baenai González \& Otero, 1984

Material studied: 1L, 2A. Genil: B14 (20 $0^{x}$ : VII-2003)

The larva of this species is not described but adults confirmed that this species was collected in the site.

Tinodes cf. dives (Pictet, 1834)

Material studied: 38L. Llobregat: H23; Foix: H31; Tajo: H8

Tinodes cf. unicolor Pictet, 1834

Material StUdied: 1L. Tordera: H14

Tinodes cf. waeneri (Linnaeus, 1758)

MATERIAL STUDIED: 14L. Ter: H29; Llobregat: H32

Family POLYCENTROPODIDAE Ulmer, 1903

Subfamily Polycentropodinae Ulmer, 1903

Plectrocnemia Stephens, 1836

We found 39 larvae of this genus in $\mathrm{H} 26, \mathrm{H} 28, \mathrm{H} 6, \mathrm{H} 8$, B1, B3, B4, B5, B9, B10, B20, B23, B27, B28, R17, R19. Specimens found in B1, B3, B4, B5, B9, B20, B27, B28 were similar to Plectrocnemia conspersa (Curtis, 1834) whereas 2 in B27 were similar to Plectrocnemia laetabilis McLachlan, 1880. However, these two species are the only ones described at larval stage (Vieira-Lanero et al., 2003) out the six species recorded in the studied area (Dakki, 1980; González et al., 1992; Tobias \& Tobias, 2007).
Polycentropus Curtis, 1835

Polycentropus cf. corniger McLachlan, 1884

MATERIAL STUDiED: 3L. Fluvià: H18; Segura: T2

Records of pupae and adults are needed to confirm the presence of this species in the study sites.

Polycentropus flavomaculatus (Pictet, 1834)

MATERIAL STUdiED: 5L. Ter: H29; Foix: H31

Polycentropus kingi McLachlan, 1881

Material StUdied: 99L. Tordera: H14, H16; Tajo: H8; Júcar: H13; Segura: T2; Guadiana Menor: B33, T7, T8; Genil: ?B18, B13, B14; Adra: B4; Guadalfeo: B24, B25; Laou: R3, R4, R8; Adelmane: R15, R16

The presence of this species in T8 is confirmed by adult collection in previous studies (Zamora-Muñoz et al., 2002).

Cyrnus Stephens, 1836

Cyrnus cf. montserrati González \& Otero, 1963

MATERIAL STUDIED: 2L. Guadiana Menor: H1

Records of pupae and adults are needed to confirm the presence of this species in the studied sites, but these larvae resembled those found in a previous study (Bonada et al., 2004b).

\section{Suborder INTEGRIPALPIA}

Superfamily LIMNEPHILOIDEA Kolenati, 1848

Family BRACHYCENTRIDAE Ulmer, 1903

Brachycentrus Curtis, 1834

Brachycentrus (B.) cf. montanus Klapálek, 1892

Material STUDied: 1L. Júcar: H13

This specimen has a squared section case without silk and the head has a uniform coloration, typical features of this species. However, until now it has only been recorded in northern Portugal and north-western Spain (Vieira-Lanero, 2000).

Brachycentrus (B.) subnubilus Curtis, 1834

MATERIAL STUDiED: 3L. Tajo: H9

Micrasema LacLachlan, 1876

Micrasema longulum McLachlan, 1876

Material studied: 8L. Genil: B9, B11; Adra: B2, B3; Guadalfeo: B22

Micrasema cf. minimum McLachlan, 1876

MATERIAL STUdiED: 5L. Ter: H25 
Although specimens fitted well under this species according to Vieira-Lanero (2000), Micrasema salardum Schmid, 1952 or Micrasema vestitum Navás, 1918, whose larvae are not yet described, have been cited close to site H25 (Estación Valter 2000, in Botosaneanu \& González, 2006)

Micrasema moestum (Hagen, 1868)

Material Studied: 283L. Tajo: H9; Guadiana Menor: B27, T5, T8; Genil: B9, B14, B17, B19; Adra: B1, B2, B3, B4, B5; Guadalfeo: B22, B23, B26; Laou: R2

The presence of this species in $\mathrm{T} 8$ has been confirmed previously by adult collection (Zamora-Muñoz et al., 2002).

Family LEPIDOSTOMATIDAE Ulmer, 1903

Subfamily Lepidostomatinae Ulmer, 1903

Lepidostoma Rambur, 1842

Lepidostoma hirtum (Fabricius, 1775)

Material Studied: 15L. Muga: H33; Tordera: H15; Júcar: T3; Guadiana: H1; Genil: B10

Lasiocephala Costa, 1857

Lasiocephala basalis (Kolenati, 1848)

MATERIAL STUdiED: 89L, 1P. Júcar: H4; Segura: T2; Guadiana Menor: T5, T8 (1Pơ': IV-2003); Genil: B9, B10, B11, B14; Adra: B4; Guadalfeo: B20, B22, B23, B26

This species has been considered as Lepidostoma basale by Malicky (2005b).

Family LIMNEPHILIDAE Kolenati, 1848

Subfamily Drusinae Banks, 1916

Drusus Stephens, 1837

Drusus bolivari (McLachlan, 1880)

MATERIAL STUDIED: 8L. Guadiana Menor: T5

Drusus rectus (McLachlan, 1868)

MATERIAL STUDIED: 2L. Ter: ?H25

Given the difficulties of separating $D$. rectus from Drusus annulatus (Stephens 1837) using larvae, we provisionally considered these specimens as D. rectus because adults have been found in ecologically similar sites of the Ter Basin (Bonada et al., 2004b).

Anomalopterygella Fischer, 1966

Anomalopterygella chauviniana (Stein, 1874)

MATERIAL STUdied: 16L. Guadiana Menor: B27; Genil: B9; Adra: B2, B3; Guadalfeo: B20, B26
Subfamily Limnephilinae Kolenati, 1848

Tribe Limnephilini Kolenati, 1848

Limnephilus Leach, 1815

Limnephilus guadarramicus Schmid, 1955

MATERIAL STUdiED: 27L. Ter: H28; Llobregat: H23; Tajo: H12; Júcar: H13; Segura: T2

Limnephilus lunatus Curtis, 1834

Material StUdied: 8L. Fluvià: H20; Tajo: H9; Júcar: T3; Laou: R2

Glyphotaelius Stephens, 1833

Glyphotaelius pellucidus (Retzius, 1783)

MATERIAL STUDIED: 5L. Ter: H28; Llobregat: H23

Tribe Chaetopterygini Hagen, 1858

Annitella Klapalek 1907

Annitella esparraguera Schmid, 1952

Material Studied: 13L, 1P, 100A. Guadiana Menor: B27

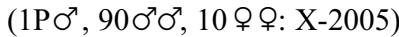

Until now, A. esparraguera, one of the eight species of this genus present in the Iberian Peninsula, had been recorded only in Sierra Nevada (Schmid, 1952a;b) and Sierra de Cazorla (Sipahiler, 1998). With this record of Sierra de Baza, we extend its distribution to other areas of the Betic Ranges. All Annitella species are rare and only the larva of $A$. obscurata (McLachlan, 1876) has been described (e.g. Vieira-Lanero, 2000), thus the genus is seldom included in larval keys. The larvae collected in this site were small (III instar) and fitted with Halesus or Chaetopteryx following the keys of Vieira-Lanero (2000) and Camargo \& García de Jalón (1988).

Chaetopteryx Stephens, 1829

We collected 1 larva of this genus in the Segura Basin (T2). The species level is not provided because of the difficulties at larval level (Vieira-Lanero, 2000).

Tribe Stenophylacini Schmid, 1955

Potamophylax Wallengren, 1891

Potamophylax cingulatus (Stephens, 1837)

MATERIAL STUdieD: 9L. Tordera: H14, H15; Ter: H17, H25, H26

Potamophylax latipennis (Curtis, 1834)

Material STUdied: 20L. Ter: H25, H26; Genil: B9, B11; Adra: B1, B2, B3, B4; Guadalfeo: B23

Halesus Stehens, 1836

Halesus radiatus (Curtis, 1834)

MATERIAL STUDIED: 25L. Ter: H24; Tordera: H16; Llobregat: H23 
Halesus tesellatus (Curtis, 1834)

Material studied: 33L. Adra: B1, B2, B3, B4, B5; Guadalfeo: B20, B22, B26

\section{Stenophylax Kolenati, 1848}

Larval description of all the species of this genus recorded in the study area (11 species) are not provided in the literature, and species level can only be reached with reliability using pupae or adults. Following the available keys for the described species (Wallace et al., 1990; Waringer \& Graf, 1997; Vieira-Lanero, 2000), we have identified 22 larvae from Ter (H28), Llobregat (H23) and Sebou (R19) basins as Stenophylax sequax (McLachlan, 1875). However, this species has not been cited in North Africa (Dakki, 1980; Tobias \& Tobias, 2007). Six larvae in the Guadiana Menor (T6) and Genil (B8) basins were identified as Stenophylax nycterobius (McLachlan, 1875), confirmed in the B8 site by larval rearing in the laboratory. On the other hand, 13 larvae in the Guadiana Menor (B30, B33 and B34) and Genil basins (B8, B10, B12 and B14) may fit with Stenophylax crossotus McLachlan, 1884 following the recent description by Ruiz-García \& Ferreras-Romero (2007).

Mesophylax McLachlan, 1882

Mesophylax aspersus (Rambur, 1842)

MATERIAL STUDiED: 1L. Llobregat: H23

Allogamus Schmid, 1955

Allogamus auricollis (Pictet, 1834)

Material STUDIED: 120L. Ter: H24

Allogamus ligonifer (McLachlan, 1876)

Material StUdied: 10L. Tajo: H12; Júcar: H4; Segura: T2, T4

Allogamus mortoni (Navás, 1907)

Material STUdied: 220L, 31A. Guadiana Menor: B32, B33, B40 (2 우 우: X-1996; $10^{7}:$ XI-1996; 2 우 우, $100^{7} \sigma^{7}:$ X-2007); Genil: B12, B13 (2 $\sigma^{7} \sigma^{7}:$ X-1996; $1 \sigma^{7}:$ XI-1996), B14 (1 ○': X2005), B16, B17 (12070': X-2007), B19; Laou: R2, R4, R5, R13, R15; Sebou: R17; Adelmane: R16

Larvae of this species were identified using the key of Ruiz-García et al. (2004) which includes all known Allogamus species of the Iberian Peninsula. In addition, some specimens from North Africa and Genil Basin were confirmed by the author of the key (Ruiz, pers. comm.) and in Guadiana Menor (B40) and Genil basins (B13, B14 and B17) we collected adults of this species. Therefore, our records would extend the distribution of this Iberian species to North Africa. The study of the male genitalia of individuals from B17 and $\mathrm{B} 40$ revealed certain variability in the number (from 2 to 4 ) and the length of the spines of the parameres. In each locality we could distinguish three morphotypes in relation to this character and in two of them the length of one of the spines was longer than in the original description of $A$. mortoni (see Malicky, 2004). Nevertheless, after comparing the individuals with specimens of Allogamus antennatus McLachlan, 1876 and Allogamus antennatus ausoniae (Moretti, 1991), our individuals never had the parameres as long as the aedeagus, like these have. The parameres of $A$. mortoni thus show a high morphological variability as noticed for A. auricollis Pictet, 1834 (see Malicky, 2004).

Family GOERIDAE Ulmer, 1903

Subfamily Goerinae Ulmer, 1903

Silo Curtis, 1830

Silo graellsii E. Pictet, 1865

MATERIAL STUDIED: 2L. Ter: H25

Silonella Fischer 1966

Silonella aurata (Hagen, 1864)

Material StUdied: 61L. Genil: B19; Laou: R2; Adelmane: R16

Larcasia Navás, 1917

Larcasia partita Navás, 1917

MATERIAL STUDIED: 3L. Guadiana: H1

Superfamily LEPTOCEROIDEA Leach, 1815 Family LEPTOCERIDAE Leach, 1815

Subfamily Leptocerinae Leach, 1815

Tribe Athripsodini Morse \& Wallace, 1976

Athripsodes Billberg, 1820

Some species of this genus (e.g. A. taounate Dakki \& Malicky, 1980) have been recorded in the study area but are not yet described (González et al., 1992). We found 36 larvae of this genus in Fluvià (H18), Ter (H29), Tajo (H5), Júcar (H4), Guadiana Menor (B29, B33), Genil (B10, B11, B12, B16), Guadalfeo (B20, B22, B26), Martil (R14) and Laou (R1) basins. Larvae found in H18 were similar to Athripsodes albifrons (Linnaeus, 1758).

Tribe Leptocerini Leach, 1815

Leptocerus Leach, 1815

Leptocerus lusitanicus McLachlan, 1884

MATERIAL STUDIED: 1L. Fluvià: H20 
Tribe Mystacidini Burmeister, 1839

Mystacides Berthold, 1827

Mystacides azurea (Linnaeus, 1761)

Material STUdied: 25L. Muga: H33; Fluvià: H20; Ter: H27, H29; Llobregat: H23; Francolí: H35; Tajo: H10; Segura: T4

Tribe Oecetini Silfvenius, 1905

Oecetis McLachlan, 1877

We found 4 larvae of this genus in Muga (H33), Ter (H27, H29) and Tordera (H16) similar to Oecetis testacea Curtis, 1834.

Tribe Setodini Morse, 1981

Setodes Rambur, 1842

Eleven specimens of this genus were found in the Laou Basin (R4, R13) but given that some species remain undescribed (e.g. Setodes zerroukii Dakki, 1981), it was not possible to reach the species level.

Setodes argentipunctellus McLachlan, 1877

MATERIAL StUdied: 47L. Fluvià: H18, H20; Francolí: H35; Tajo: H8, H9; Guadiana: H1; Segura: T2, T4; Guadalquivir: H6; Genil: B18; Guadalfeo: ?B24, ?B25; Chillar: ?B7; Verde: ?B35

Tribe Triaenodini Morse, 1981

Adicella McLachlan, 1877

Adicella reducta (McLachlan, 1865)

Material studied: 20L, 1A. Tordera: H14, Guadiana Menor: B29, T8; Genil: B10, B14 (10: X-2005), B16, B17, B18; Adra: B5; Guadalfeo: B20

The genus has some species with undescribed larvae (e.g. Adicella melanella (McLachlan, 1884)) but the presence of $A$. reducta in the study area has been confirmed by adults previously collected in the sites from Tordera, Guadiana Menor and Guadalfeo basins (Zamora-Muñoz, unpubl. data and see also Zamora-Muñoz et al., 2002; Bonada et al., 2004b) and now in the Genil Basin.

Family CALAMOCERATIDAE Ulmer, 1905

Subfamily Calamoceratinae Ulmer, 1905

Calamoceras Brauer, 1865

Calamoceras marsupus Brauer, 1865

Material Studied: 14L. Tordera: H16; Guadiana: H1; Segura: T2, T4; Guadalquivir: H6

Calamoceras gr. marsupus Brauer, 1865

MATERIAL StUdied: 150L, 3P. Martil: R14; Adelmane: R15, R16 (1Po', 1P 우: VI-2003); Laou: R2, R3, R4, R5, R8, R13 (1PO': XII-2003); Sebou: R18
In spite of larvae of $C$. marsupus building their cases with vegetable material (García de Jalón et al., 1987), some larval specimens in R8 presented a stony case. Adults collected did not fit clearly under the male genitalia description of C. marsupus or Calamoceras illiesi Malicky \& Kumanski, 1974, another species present in the Mediterranean Basin (Malicky, 2005a), and in some features our specimens present intermediate characteristics (González, pers. comm.). In ventral view, the IXth segment is shorter in our specimens than in C. marsupus, with the lateral edges more developed, particularly in the distal end. In lateral view, the ventral lobes of Xth segment present a small blunted tooth, as in C. illiesi. Gonopods of our specimens resemble those of $C$. marsupus, but they have the basal segment more slender and the distal segment (harpago) longer (about as long as basal segment) than this species. Considering that $C$. marsupus and $C$. illiesi have small differences in the genitalia and there is some morphological variability in the Mediterranean Basin (Malicky, in letter to N. Bonada), we can not ensure the identification of these specimens until more adults are collected.

Family ODONTOCERIDAE Wallengren, 1891

Subfamily Odontocerinae Wallengren, 1891

Odontocerum Leach, 1815

Odontocerum albicorne (Scopoli, 1763)

MateRial studied: 37L. Ter: H25, H26; Tordera: H15, H16

Superfamily SERICOSTOMATOIDEA Stephens, 1836 Family SERICOSTOMATIDAE Stephens, 1836

Sericostoma Latreville, 1825

Larvae within this genus are very difficult to identify at species level. We provide specimens of this genus collected in the sampled area.

Material StUdied: 68L. Muga: H33; Fluvià: H18; Ter: H17; Tordera: H4; Foix: ?H31; Tajo: H12; Júcar: H4, T3; Segura: T2; Guadiana Menor: B27, B28, B29, B31, B33, T5, T8; Genil: B10, B12, B13, B16, B17, B18; Adra: B3, B4, B5; Guadalfeo: B20, B22, B23; Laou: ?R2, ?R13

Specimens collected in T8 may correspond to Sericostoma vittatum Rambur, 1842, a species collected in this site in previous studies (Zamora-Muñoz et al., 2002). Specimens from R2 and R13 were classified as Sericostoma according to Vieira-Lanero (2000), but this genus has not been recorded from North Africa (Dakki, 1980; Tobias \& Tobias, 2007).

Schizopelex McLachlan, 1876

Schizopelex festiva (Rambur, 1842)

MATERIAL STUdied: 83L. Martil: R14; Laou: R2, R13; Adelmane: R15, R16

Graellsia, 64(2), Diciembre 2008, pp. 189-208 - ISSN: 0367-5041 


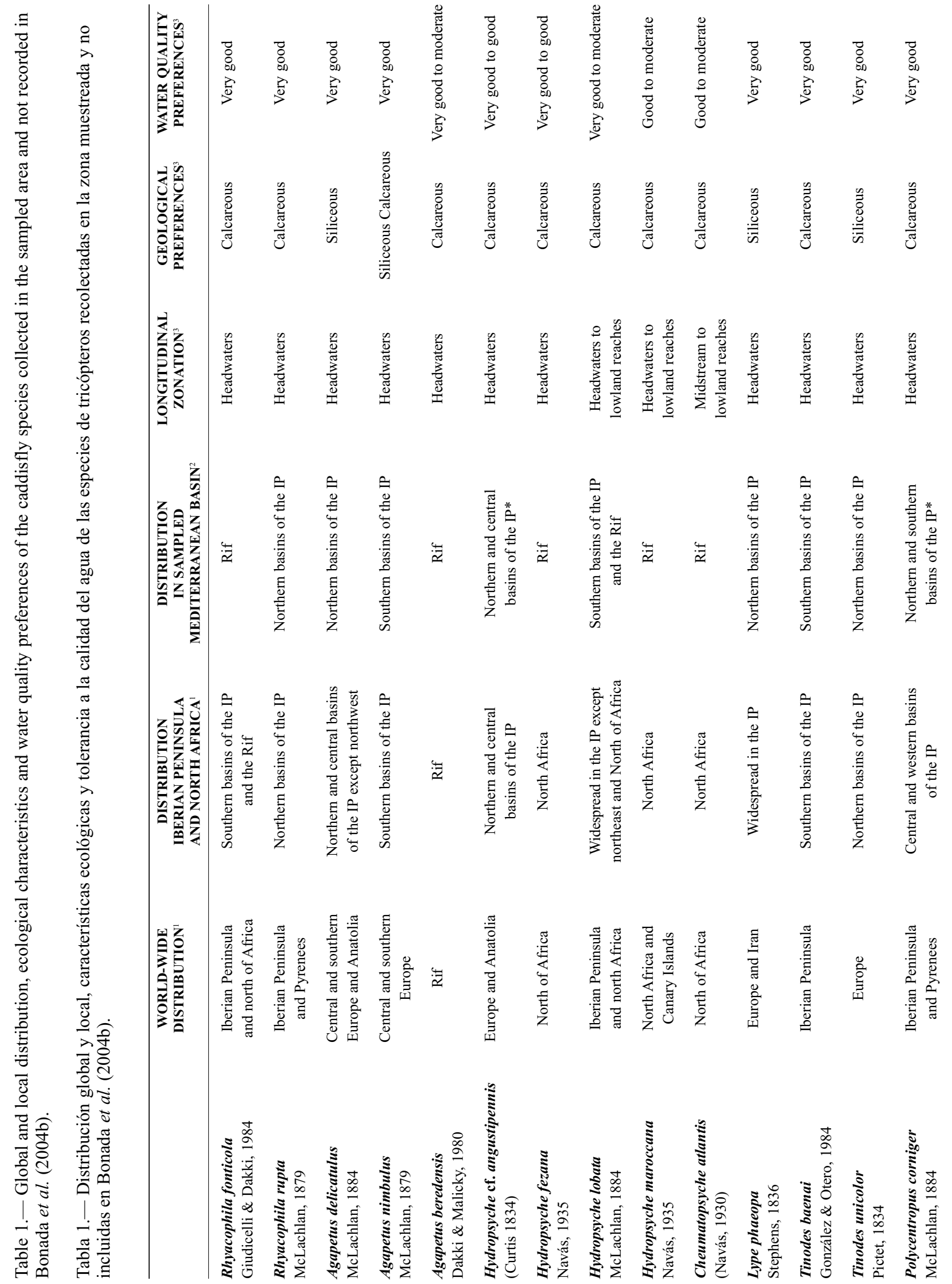




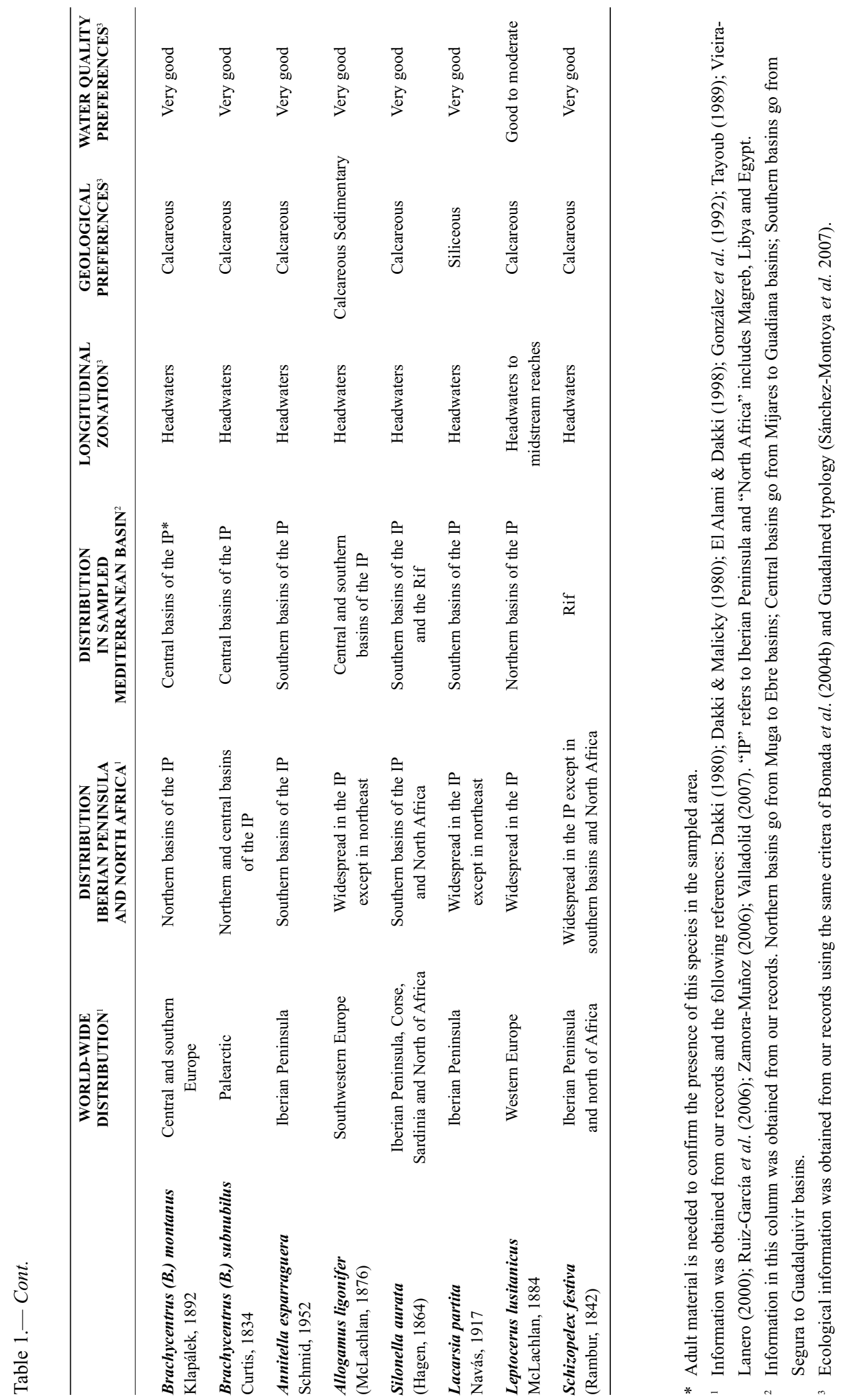


Family BERAEIDAE Wallengren, 1891

Beraea Stephens, 1833

Eight larvae of this genus were found in Tajo (H8), Guadiana (H1) and Guadalquivir (H6) basins, and resembled Beraea terrai Malicky, 1975. However, species level was not reached because the larva of Beraea dira McLachlan, 1875 is not described and could be present in the area (González et al., 1992).

Beraea maurus (Curtis, 1834)

MATERIAL STUDiED: 1L. Llobregat: H23

\section{Local richness}

From the 86 species identified with certainty in this study, 60 species were present in the Iberian plate region, 29 in the Transition, 30 in the Betic and 18 in the Rif. Although Rif showed the lowest regional species richness, local richness was not significantly different between geological regions (F-value $=2.457, \mathrm{p}=0.068)$. Significant differences were however found between ecotypes within regions $(\mathrm{F}$-value $=4.097, \mathrm{p}=0.004)$. Residuals did not significantly differ from normality $(p=$ $0.70)$ and from homogeneity of variances ( $p>$ $0.160)$. Box-plots indicated that temporary sites (Fig. 2) had lower local richness than other ecotypes in all regions except in the Rif. Headwaters, regardless of their geology, had similar richness and, when present, richness in lowland sites was also similar to that present in headwaters.

\section{Discussion}

Our work complements records reported in previous studies in the Mediterranean climate region of the Iberian Peninsula and north Africa (e.g. Dakki, 1980; Ruiz et al., 2001; Bonada et al., $2004 b$ ) with information from several not previously studied sites. We have found 22 species not recorded in Bonada et al. (2004b), 4 of them only found in the Rif. Information about the distribution of these species and their ecological requirements is provided in Table 1 . In addition, comparing with González et al. (1992) and Bonada et al. (2004b) we provide records that extend the distribution of several species in the Mediterranean area of the Iberian Peninsula. Glossosoma boltoni, Allogamus ligonifer, Lepidostoma hirtum and Lacarsia partita were recorded in the southern basins. Brachycen-

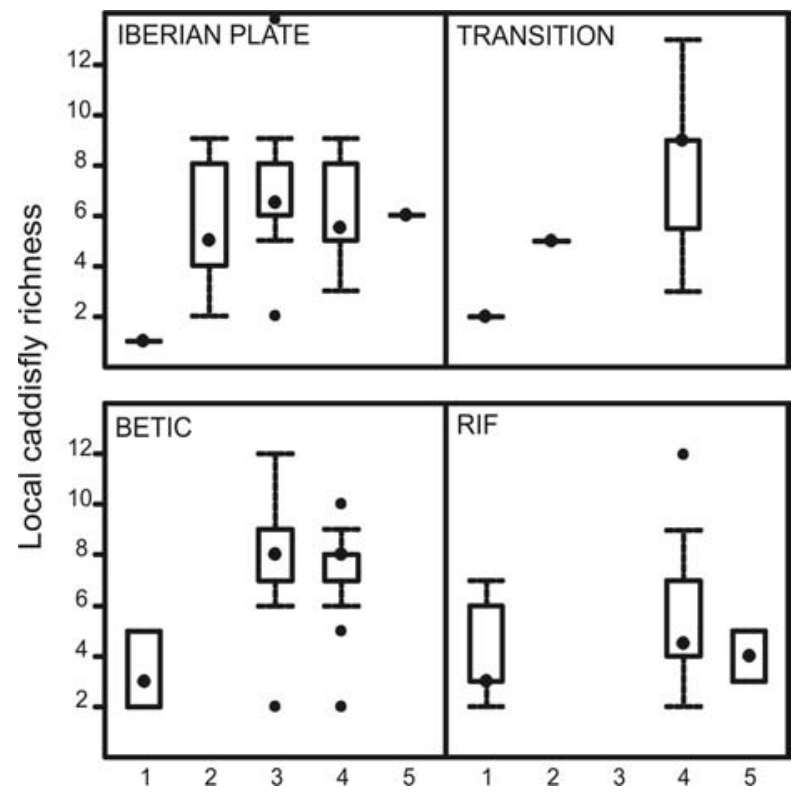

Fig. 2.- Box-plots indicating local species richness in each geological region separated by ecotypes, according to SánchezMontoya et al. (2007): (1) temporary streams, (2) evaporite calcareous streams at medium altitude, (3) siliceous headwaters at high altitude, (4) calcareous headwaters at medium and high altitude and (5) large watercourses. Each box-plot shows the medians (horizontal bars) and the 25th and 75th percentiles (boxes).

Fig. 2.- Diagramas de cajas indicando la riqueza local de especies en cada región geológica separada por ecotipos, según Sánchez-Montoya et al. (2007): (1) ríos temporales, (2) ríos calcáreos y evaporíticos de mediana altitu, (3) cabeceras silíceas de elevada altitud, (4) cabeceras calcáreas de mediana y elevada altitud y (5) grandes cursos de agua. Cada diagrama muestra las medianas (líneas horizontales) y los percentiles 25 y 75 (cajas).

trus (B.) montanus, Rhyacophila meridionalis and Limnephilus lunatus were also present in central basins. Calamoceras marsupus was also collected in northern basins.

Regional species richness differed between geological regions, with Rif having the lowest number. This observation contrasts in part with results on terrestrial plants and mammals which revealed high taxa richness in the southern Iberian Peninsula and North Africa (e.g. see Cheylan, 1991; Médail \& Quézel, 1997). This value is partially biased because the geological regions occupy different areas, (i.e. richness increases with the area considered, Gaston \& Blackburn, 2000) and because faunistic studies are scarce in the Rif (e.g. for 
Coleoptera, Bennás et al., 1992; Ribera, 2000). However, the Rif has been considered an isolated area (Jolly et al., 1998; Cosson et al., 2005), which makes the maintenance of a diverse freshwater fauna more difficult. This is even more problematic for caddisflies, which are not equipped with biological strategies to cope with the frequent summer droughts of the region (Littmann, 2000; Williams, 2006). This observation is in accordance with the lowest local caddisfly richness recorded in the ecotype 1 that we found in all geological regions except in the Rif. All this suggestd that conservation measures have to be enforced in this area to preserve its biodiversity.

Several authors have pointed out the importance of large-scale characteristics on macroinvertebrate distributions (e.g. Sandin \& Johnson, 2004). In particular, basin geology and river zonation were considered, among several environmental variables, the most important to explain caddisfly distribution in the Mediterranean climate rivers of the Iberian Peninsula (Bonada et al., 2005). Basin geology determines mineralization of water and river zonation results in changes in the hydraulic forces, the terrestrial influence and the resources available among others (Hawkins \& Sedell, 1981; Statzner et al., 1988; Leland \& Porter, 2000). However, although these parameters constrain caddisfly distribution, our results show that taxa richness is maintained between ecotypes with permanent flow conditions. This observation contrasts with other studies in temperate Europe using caddisflies that recorded an increase of species with surrogates of river zonation, such as stream width and slope (Wiberg-Larsen et al., 2000). The higher biodiversity of caddisflies in the Western Mediterranean compared to temperate Europe (e.g. around 200 species in Denmark and England, but almost double in the Iberian Peninsula, Wallace et al., 1990; González et al., 1992; Edington \& Hildrew, 1995; Wiberg-Larsen et al., 2000) is probably accountable to this observation.

\section{ACKNOWLEDGEMENTS}

This study was supported by an international cooperation project between Spain and Morocco administrations (70/04/P/E) financed by the Spanish Agency for International Cooperation (AECI), the European Project EUROLIMPACS (GOCE-CT2003-505540. 2004-2009), the GUADALMED 2 project (REN2001-3438-C07) financed by the Spanish Ministry of Science and Technology, and a Juan de la Cierva contract from the Spanish Ministery of Education and Science. We are very grateful to Mohammed Dakki and all the MEDA, MEDCOR and GUADALMED project members for data collection, to Fernanda Cianficconi for providing specimens of Allogamus antennatus and A. antennatus ausoniae from Italy and to Marcos González for taxonomical review of specimens of Allogamus mortoni and Calamoceras gr. marsupus. Special thanks to José Luis Moreno and Cáliz Navarro for providing specimens from central basins, to Marta Sáinz for helping in data collection and identification, and to Marcos González and one anonymous referee for comments on the manuscript.

\section{References}

Balleto, E. \& Casale, A., 1989. Mediterranean insect conservation. In: N.M. Collins \& J.A. Thomas (eds.). The conservation of insects and their habitats. Academic Press. London: 121-142.

Bennás, N., SÁinz-CAntero, C. E. \& Alba-Tercedor, J., 1992. Datos preliminares para un estudio biogeográfico del macizo Bético-Rifeño basado en coleópteros acuáticos. Zoologica Baetica, 3: 167-180.

Bonada, N., Prat, N., Munné, A., Rieradevall, M., Alba-Tercedor, J., Álvarez, M., Avilés, J., CASAs, J., Jaimez-Cuéllar, J., Mellado, A., MoyÁ, G., Pardo, I., Robles, S., Ramon, G., SuÁrez, M. L., Toro, M., Vival-Abarca, M. R., Vivas, S. \& ZAMORA-MuÑOZ, C., 2004a. Criterios para la selección de condiciones de referencia en los ríos mediterráneos. Resultados del proyecto GUADALMED. Limnetica, 31(2002): 99-114.

Bonada, N., Zamora-Muñoz, C., Rieradevall, M. \& PrAT, N., 2004b. Trichoptera (Insecta) collected in Mediterranean river basins of the Iberian Peninsula: Taxonomic remarks and notes on ecology. Graellsia, 60(1): 41-69.

Bonada, N., Zamora-Muñoz, C., Rieradevall, M. \& PRAT, N., 2005. Ecological and historical filters constraining spatial caddisfly distribution in Mediterranean rivers. Freshwater Biology, 50(5): 781-797.

Botosaneanu, L. \& GonzÁlez, M. A., 2006. Un difficule problème de taxonomie: les Micrasema (Trichoptera: Brachycentridae) des eaux courantes de la Péninsule Ibérique et des Pyrénées. Annales de la Société Entomologique de France, 42(1): 119-127.

CAmargo, J. A. \& García de JALÓN, D., 1988. Principales características morfológicas de los géneros ibéricos de la familia Limnephilidae (Trichoptera) en sus últimos estadios larvarios. Boletín de la Asociación Española de Entomología, 12: 239-258.

Cheylan, G., 1991. Patterns of Pleistocene turnover, current distribution and speciation among Mediterranean mammals. In: R.H. Groves \& F. di Castri (eds.). Biogeography of Mediterranean Invasions. Cambridge University Press. Cambridge: 227-262.

Cosson, J.-F., Hutterer, R., Libois, R., SArÀ, M., TABerlet, P. \& Vogel, P., 2005. Phylogeographical footprints of the Strait of Gibraltar and Quaternary climatic fluctuations in the western Mediterranean: a case study with the greater white-toothed shrew, 
Crocidura russula (Mammalia: Soricidae). Molecular Ecology, 14: 1151-1162.

DAKKI, M., 1980. Étude nationale sur la biodiversité: faune aquatique continentale (invertébrés et poissons). Royaume du Maroc, Ministere de l'Environnement, Direction de l'Observation, des Études et de la Coordination. Rabat. 70 pp.

DAKKI, M. \& Malicky, H., 1980. Drei neue Köcherfliegen (Trichoptera) aus Marokko. Zeitschrift der Arbeitsgemeinsehaft Öster Entomologen, 31(3/4): 103-105.

Edington, J. M. \& Hildrew, A. G., 1995. A Revised Key to the Caseless Caddis Larvae of the British Isles, with Notes on their Ecology. Freshwater Biological Association Publications. Ambleside. 134 pp.

El Alami, M. \& Dakki, M., 1998. Peuplements de Trichoptères et d'Ephéméroptères de l'Oued Laou (Rif Occidentale, Maroc): distribution longitudinale et biotypologie. Bulletin de l'Institut Scientifique, 21: 51-70.

Gaston, K. J. \& Blackburn, J. H., 2000. Pattern and process in macroecology. Blackwell Science. Oxford. 377 pp.

GonzÁlez, M. A., 2007. El Reino Animal en la Península Ibérica y las Islas Baleares. Orden Trichoptera. www.fauna-iberica.mncn.csic.es/faunaib/arthropo$\mathrm{da} /$ insecta/Trichoptera/index.php.

GonzÁlez, M. A. \& MAlicky, H., 1999. Une nouvelle espèce de Hydropsyche du groupe pellucidula (Trichoptera, Hydropsychidae). Braueria, 26: 25-26.

GonzÁLEZ, M. A. \& RuIZ, A., 2001. Une nouvelle espèce de Trichoptère du Sud de l'Espagne: Allogamus gibraltaricus n. sp. (Trichoptera: Limnephilidae). Annales de Limnologie, 37(3): 219-221.

GonzÁlez, M. A., Terra, L. S. W., García de Jalón, D. \& CoBO, F., 1992. Lista faunística y bibliográfica de los Tricópteros (Trichoptera) de la Península Ibérica e Islas Baleares. Asociación Española de Limnología. Madrid. 200 pp.

Hawkins, C. P. \& Sedell, J. R., 1981. Longitudinal and seasonal changes in functional organization of macroinvertebrate communities in four Oregon streams. Ecology, 62: 387-397.

Hewitt, G. M., 2004. The structure of biodiversity insights from molecular phylogeography. Frontiers in Zoology, 1(4): 1-16.

Jolly, D., Harrison, S. P., Damnati, B. \& Bonnefille, R., 1998. Simulated climate and biomes of Africa during the late quaternary: comparison with pollen and lake status data. Quaternary Science Reviews, 17(6-7): 629-657.

KÖPPEN, W., 1931. Grundriss der Klimakunde. Walter de Gruyter. Berlin. 388 pp.

KumAnsKi, K., 2006. Trichoptera from Tunisia collected by S. Beshkov \& B. Schacht, 15-21.IV.2006. Braueria, 33: 17-19.
Leland, H. V. \& Porter, S. D., 2000. Distribution of benthic algae in the upper Illinois River basin in relation to geology and land use. Freshwater Biology, 44(2): 279-301.

LITTMANN, T., 2000. An empirical classification of weather types in the Mediterranean Basin and their interrelation with rainfall. Theoretical and Applied Climatology, 66: 161-171.

Malicky, H., 2002. The sub-specific division of Rhyacophila dorsalis Curtis, 1834 and its transitions to $R$. nubila Zetterstedt, 1840 (Trichoptera: Rhyacophilidae). Proceedings of the $10^{\text {th }}$ International Symposium on Trichoptera, 15: 149-166.

Malicky, H., 2004. Atlas of European Trichoptera. 2nd edn. Springer. Dordrecht. 359 pp.

Malicky, H., 2005a. Die Köcherfliegen Griechenlands. Biologiezentrum. Linz. 240 pp.

MaLiCKY, H., 2005b. Ein kommentiertes Verzeichnis der Köcherfliegen (Trichoptera) Europas und des Mediterrangebietes. Linzer biologische Beiträge, 37(1): 533-596.

Malicky, H. \& LounAcI, A., 1987. Beitrag zur Taxonomie und Faunistik der Köcherfliegen von Tunesien, Algerien und Marokko (Trichoptera). Opuscula Zoologica Fluminensia, 14: 1-20.

MÉDAIL, F. \& QuÉzEL, P., 1997. Hot-spots analysis for conservation of plant biodiversity in the Mediterranean Basin. Annals of the Missouri Botanical Garden, 84: 112-127.

Myers, N., Mittermeier, R. A., Mittermeier, C. G., DA FonsecA, G. A. B. \& Kent, J., 2000. Biodiversity hotspots for conservation priorities. Nature, 403: 853558.

Neu, P. J. \& Tobias, W., 2003. Digitale Schlüssel zur Bestimmung der in Deutschland vorkommenden Hydropsychidae (Insecta: Trichoptera). CD-Version $200703 a$.

PITSCH, T., 1993. Zur Larvaltaxonomie, Faunistik und Ökologie mitteleuropäischer Fliebwasser-Köcherfliegen (Insecta: Trichoptera). Landschaftsentwicklung und Umweltforschung, Sorderheft S 8(D 188): 192-214.

QuinN, G. P. \& KeOugh, M. J., 2002. Experimental design and data analysis for biologists. Cambridge University Press. Cambridge. 537 pp.

RIBERA, I., 2000. Biogeography and conservation of Iberian water beetles. Biological Conservation, 92: 131-150.

Ruiz, A. \& FErreras-Romero, M., 2007. The larva and life history of Stenophylax crossotus McLachlan, 1884 (Trichoptera: Limnephilidae) in an intermittent stream from the southwest of the Iberian Peninsula. Aquatic Insects, 29(1): 9-16.

Ruiz, A., Salamanca-Ocaña, J. C. \& Ferreras-Romero, M., 2001. Fauna de tricópteros (Insecta: Trichoptera) de cursos de agua que drenan canutos del Parque Natural 
Los Alcornocales (sur de España). Boletín de la Asociación Española de Entomología, 25(3-4): 105-120.

Ruiz, A., Salamanca-Ocaña, J. C. \& Ferreras-Romero, M., 2004. The larva of Agapetus incertulus McLachlan, 1884 (Trichoptera, Glossosomatidae). Aquatic Insects, 26(3/4): 153-159.

Ruiz-García, A., Herrera Grao, A. F. \& FerrerasRoMero, M., 2006. Distribution of Trichoptera communities in the Hozgarganta Catchment (Los Alcornocales Natural Park, SW Spain). International Review of Hydrobiology, 91(1): 71-85.

Ruiz-García, A., Salamanca-Ocaña, J. C. \& FerrerasRomero, M., 2004. The larvae of Allogamus gibraltaricus González \& Ruiz, 2001 and Allogamus mortoni (Navás, 1907) (Trichoptera, Limnephilidae), two endemic species of the Iberian Peninsula. Annales de Limnologie, 40(4): 343-349.

SÁnchez-Montoya, M. M., Puntí, T., SuÁrez, M. L., Vidal-Abarca, M. R., Rieradevall, M., Poquet, J. M., Zamora-Muñoz, C., Robles, S., Álvarez, M., Alba-Tercedor, J., Toro, M., Pujante, A. M., Munné, A. \& PRAT, N., 2007. Concordance between ecotypes and macroinvertebrate assemblages in Mediterranean streams. Freshwater Biology, 52(5): 939-958.

SAndin, L. \& Johnson, R. K., 2004. Local, landscape and regional factors structurig benthic macroinvertebrate assemblages in Swedish streams. Landscape Ecology, 19: 501-514.

SAnZ de Galdeano, C. \& Vera, J. A., 1991. Una propuesta de clasificación de las cuencas neógenas béticas. Acta Geologica Hispanica, 26(3-4): 205-227.

ScHMID, F., 1952a. Contribution a l'étude des Trichoptères d'Espagne. Pirineos, 26: 627-695.

SCHMID, F., 1952b. Le groupe de Chaetopteryx (Limnophilidae, Trichoptera). Revue Suisse de Zoologie, 59: 7-171.

SIPAHILER, F., 1998. Studies on the genus Annitella Klapálek (Trichoptera: Limnephilidae: Chaetopterygini) in the Iberian Peninsula. Aquatic Insects, 20(3): 149-164.

Statzner, B., Gore, J. A. \& Resh, V. H., 1988. Hydraulic stream ecology: observed patterns and potential applications. Journal of the North American Benthological Society, 7(4): 307-360.

TAYOUB, H., 1989. Étude hydrobiologique d'un réseau hydrographique rifain, l'oued Laou: Typologie et Ecologie des Trichoptères. In: Faculty of Sciences. University of Mhammed V Agdal, Rabat: 137.

ToBiAs, D. \& ToBiAs, W., 2007. Trichoptera Africana: Köcherflieggen der westpaläarktischen und afrotropischen Regionen Afrikas - Arbeitsunterlagen. http://user.uni-frankfurt.de/ wtobias/.

Valladolid, M., Martínez-Bastida, J. J. \& Arauzo, M., 2007. Los Hydropsychidae (Insecta: Trichoptera) del río Oja (La Rioja, España). Limnetica, 26(1): 199-208.
VIEIRA-LANERO, R., 2000. Las larvas de los tricópteros de Galicia (Insecta: Trichoptera). PhD thesis. Department of Animal Biology, University of Santiago de Compostela. $611 \mathrm{pp}$.

Vieira-Lanero, R., González, M. A. \& Cobo, F., 2003. The larva of Plectrocnemia laetabilis McLachlan, 1880 (Trichoptera; Polycentropodidae; Polycentropodinae). Annales de Limnologie, 39(2): 135-139.

Vieira-Lanero, R., GonzÁlez, M. A., Ruiz-García, A. $\&$ CoBO, F., 2008. The larva and female of Rhyacophila fonticola Guidicelli \& Dakki, 1984 (Trichoptera: Rhyacophilidae), an interesting BeticRifean endemic species. Aquatic Insects, 30: 21-28.

Vinson, M. R. \& Hawkins, C. P., 2003. Broad-scale geographical patterns in local stream insect genera richness. Ecography, 26: 751-767.

Wallace, I. D., Wallace, B. \& Philipson, G. N., 1990. $A$ key to the case-bearing caddis larvae of Britain and Ireland. Freshwater Biological Association Publications. Ambleside. 237 pp.

WARINGER, J. \& GRAF, W., 1997. Atlas der Östrreichischen Köcherfliegenlarven: unter Einschluss der angrenzenden Gebiete. Facultas-Universitätsverlag. Vienna. 286 pp.

Wiberg-Larsen, P., Brodersen, K. P., Birkholm, S., Grons, P. N. \& Skriver, J., 2000. Species richness and assemblage structure of Trichoptera in Danish streams. Freshwater Biology, 43: 633-647.

Wiggins, G. B., 1996. Larvae of the North American Caddisfly Genera (Trichoptera). 2nd edn. University of Toronto Press. Toronto. $457 \mathrm{pp}$.

Williams, D. D., 2006. The biology of temporary waters. Oxford University Press. New York. 337 pp.

Zamora-Muñoz, C., Alba-Tercedor, J. \& García de JALÓN, D., 1995. The larvae of the genus Hydropsyche (Hydropsychidae; Trichoptera) and key for the identification of the Iberian Peninsula. Mitteilungen der Münchner Entomologischen Gesellschaft, 68: 189-210.

Zamora-Muñoz, C., GonzÁlez, M. A., PiCAzo-Muñoz, J. \& AlbA-TERCEDOR, J., 2002. Hydropsyche fontinalis, a new species of the instabilis-group from the Iberian Peninsula (Trichoptera, Hydropsychidae). Aquatic Insects, 24(3): 189-197.

Zamora-Muñoz, C., Poquet, J. M., Alba-Tercedor, J. \& BONADA, N., 2006. First record of Agapetus nimbulus McLachlan, 1879 (Trichoptera: Glossosomatidae) in the Iberian Peninsula. Boletín de la Asociación Española de Entomología, 30(3-4): 187-189.

Recibido, 7-III-2008 Aceptado, 29-VII-2008 Publicado, 29-XII-2008 
Appendix.- Location of the sampled sites in the Iberian Peninsula and the Rif. For each site the code used in the text, UTM coordinates, altitude, river name, geographical province and ecotype are shown. Ecotype refers to the categories provided by SánchezMontoya et al. (2007) and corresponds to: (1) temporary streams, (2) evaporite calcareous streams at medium altitude, (3) siliceous headwaters at high altitude, (4) calcareous headwaters at medium and high altitude and (5) large watercourses. Sites are arranged by alphabetical order of "Code".

Apéndice.- Localización de las estaciones muestreadas en la Península Ibérica y en el Rif. Para cada estación se presenta el código utilizado en el texto, las coordenadas UTM, la altitud, el nombre del río, la provincia geográfica y el ecotipo. El ecotipo incluye las categorías consideradas en Sánchez-Montoya et al. (2007) y corresponden a: (1) ríos temporales, (2) ríos calcáreos y evaporíticos de mediana altitud, (3) cabeceras silíceas de elevada altitud, (4) cabeceras calcáreas de mediana y elevada altitud y (5) grandes cursos de agua. Los puntos de muestreo están ordenados por orden alfabético del "Code".

\begin{tabular}{|c|c|c|c|c|c|c|c|}
\hline Code & Basin & ongitudeX_UTM & Latitude Y_UTM & Altitude m.a.s.l. & River/Stream & Province & Ecotype \\
\hline B1 & Adra & 498290 & 4103820 & 1700 & Palancón & Granada & 3 \\
\hline $\mathrm{B} 10$ & Genil & 468522 & 4121199 & 1300 & Aguas Blancas & Granada & 4 \\
\hline B11 & Genil & 465699 & 4109998 & 1140 & Genil & Granada & 3 \\
\hline B12 & Genil & 455172 & 4123899 & 1200 & Polvorite & Granada & 4 \\
\hline B13 & Genil & 453445 & 4126399 & 1200 & Bermejo & Granada & 4 \\
\hline B14 & Genil & 454628 & 4122600 & 1140 & Darro & Granada & 4 \\
\hline B15 & Genil & 429705 & 4083091 & 1050 & Vacal & Granada & 4 \\
\hline B16 & Genil & 412225 & 4087293 & 1060 & Cerezal & Granada & 4 \\
\hline B17 & Genil & 420727 & 4086147 & 970 & Añales & Granada & 4 \\
\hline B18 & Genil & 425692 & 4086083 & 920 & Cebollón & Granada & 4 \\
\hline B19 & Genil & 422518 & 4081479 & 1040 & Venta Vicario & Granada & 4 \\
\hline B2 & Adra & 488292 & 4101823 & 1940 & Mecina & Granada & 3 \\
\hline B20 & Guadalfeo & 463688 & 4091493 & 1740 & Chico & Granada & 3 \\
\hline B21 & Guadalfeo & 459618 & 4081602 & 230 & Guadalfeo & Granada & 3 \\
\hline B22 & Guadalfeo & 469060 & 4094300 & 1650 & Poqueira & Granada & 3 \\
\hline B23 & Guadalfeo & 457451 & 4095783 & 1860 & Torrente & Granada & 3 \\
\hline B24 & Guadalfeo & 479411 & 4084328 & 760 & Verdebique & Granada & 1 \\
\hline B25 & Guadalfeo & 443614 & 4079504 & 550 & Toba & Granada & 4 \\
\hline B26 & Guadalfeo & 477400 & 4096700 & 1500 & Trevélez & Granada & 3 \\
\hline $\mathrm{B} 27$ & Guadiana Menor & or 512899 & 4133686 & 1750 & Gor & Granada & 4 \\
\hline B28 & Guadiana Menor & r 510798 & 4129412 & 1720 & Casas Don Diego & Granada & 1 \\
\hline B29 & Guadiana Menor & r 521226 & 4127424 & 1520 & Moras & Granada & 3 \\
\hline B3 & Adra & 492180 & 4103027 & 1820 & Nechite & Granada & 3 \\
\hline B30 & Guadiana Menor & r $\quad 457297$ & 4127800 & 1350 & Perdices & Granada & 1 \\
\hline B31 & Guadiana Menor & or 507418 & 4139482 & 1280 & Baúl & Granada & 1 \\
\hline B32 & Guadiana Menor & r 461115 & 4128569 & 1240 & Fardes & Granada & 4 \\
\hline B33 & Guadiana Menor & r 465822 & 4132961 & 1300 & Sillar & Granada & 4 \\
\hline B34 & Guadiana Menor & r $\quad 475801$ & 4122564 & 1160 & Rambla Seca & Granada & 1 \\
\hline B35 & Verde & 432919 & 4078701 & 850 & Verde & Málaga & 4 \\
\hline B36 & Jara & 463550 & 3998550 & 54 & Jara & Cádiz & 2 \\
\hline B37 & Guadalfeo & 459660 & 4081550 & 220 & Guadalfeo & Granada & 3 \\
\hline B38 & Aguas & 582630 & 4105270 & 260 & Aguas & Almería & 2 \\
\hline B39 & Aguas & 584450 & 4105580 & 210 & Aguas & Almería & 2 \\
\hline B40 & Guadiana Menor & r 459100 & 4130900 & 1400 & Fuente Grande & Granada & 4 \\
\hline B4 & Adra & 495910 & 4102660 & 1840 & Laroles & Granada & 3 \\
\hline B41 & Almanzora & 550050 & 4131020 & 800 & Bacares & Almería & 3 \\
\hline B42 & Almanzora & 549350 & 4129050 & 920 & Bacares & Almería & 3 \\
\hline
\end{tabular}




\begin{tabular}{|c|c|c|c|c|c|c|c|}
\hline Code & Basin & LongitudeX_UTM & Latitude Y_UTM & Altitude m.a.s.l. & River/Stream & Province & Ecotype \\
\hline B43 & Genil & 463242 & 4111817 & 1060 & Maitena & Granada & 3 \\
\hline B5 & Adra & 491011 & 4100816 & 1840 & Válor & Granada & 3 \\
\hline B6 & Chillar & 420500 & 4073500 & 320 & Frigiliana & Málaga & 4 \\
\hline B7 & Chillar & 421323 & 4072005 & 150 & Chillar & Málaga & 4 \\
\hline B8 & Genil & 456265 & 4130764 & 1720 & Blanco & Granada & 1 \\
\hline B9 & Genil & 465800 & 4109088 & 1390 & San Juan & Granada & 3 \\
\hline H1 & Guadiana & 363828 & 4380419 & 828 & Estena & Toledo & 3 \\
\hline H10 & Tajo & 468100 & 4433400 & 510 & Tajo & Toledo & 4 \\
\hline H11 & Guadiana & 515688 & 4414636 & 792 & Gigüela & Cuenca & 4 \\
\hline H12 & Tajo & 593100 & 4499800 & 1200 & Cabrillas & Cuenca & 4 \\
\hline H13 & Júcar & 606000 & 4403400 & 855 & Guadazaón & Cuenca & 4 \\
\hline H14 & Tordera & 947953 & 4638984 & 660 & Tordera & Barcelona & 3 \\
\hline H15 & Tordera & 953190 & 4639974 & 1264 & Gualba & Barcelona & 3 \\
\hline H16 & Tordera & 964927 & 4629108 & 237 & Fuirosos & Barcelona & 3 \\
\hline H17 & Ter & 947757 & 4645608 & 840 & Sant Gesimon & Girona & 3 \\
\hline H18 & Fluvià & 953461 & 4698798 & 474 & Beget & Girona & 4 \\
\hline H19 & Fluvià & 961308 & 4695600 & 338 & Llierca & Girona & 1 \\
\hline $\mathrm{H} 20$ & Fluvià & 986046 & 4686692 & 61 & Fluvià & Girona & 4 \\
\hline H21 & Llobregat & 910416 & 4690484 & 924 & Llobregat & Barcelona & 4 \\
\hline $\mathrm{H} 22$ & Llobregat & 885813 & 4667486 & 696 & Aigua d'Ora & Barcelona & 2 \\
\hline $\mathrm{H} 23$ & Llobregat & 923805 & 4651193 & 674 & Postius & Barcelona & 4 \\
\hline $\mathrm{H} 24$ & Ter & 936193 & 4706897 & 1517 & Ter & Girona & 3 \\
\hline H25 & Ter & 944006 & 4706387 & 1271 & Ritort & Girona & 3 \\
\hline H26 & Ter & 939892 & 4678006 & 1001 & Ges & Girona & 4 \\
\hline $\mathrm{H} 27$ & Ter & 930440 & 4677961 & 617 & Ter & Girona & 4 \\
\hline H28 & Ter & 929406 & 4649002 & 755 & Mèder & Barcelona & 4 \\
\hline H29 & Ter & 966413 & 4662199 & 152 & Ter & Girona & 5 \\
\hline H3 & Guadiana & 356597 & 4333266 & 449 & Guadiana & Ciudad Real & 2 \\
\hline H30 & Ter & 976153 & 4662597 & 102 & Ter & Girona & 5 \\
\hline H31 & Foix & 883914 & 4595890 & 488 & Albereda & Barcelona & 2 \\
\hline H32 & Llobregat & 881101 & 4606808 & 454 & Carme & Barcelona & 4 \\
\hline H33 & Muga & 989804 & 4714975 & 314 & Anyet & Girona & 3 \\
\hline H34 & Calonge & 998498 & 4652791 & 157 & Calonge & Girona & 1 \\
\hline H35 & Francolí & 846355 & 4581390 & 531 & Brugent & Tarragona & 2 \\
\hline H36 & Besòs & 924622 & 4628706 & 601 & Caldes & Barcelona & 4 \\
\hline H37 & Ebre & 269545 & 4524131 & 618 & Algars & Tarragona & 4 \\
\hline H38 & Guadalquivir & 517300 & 4306800 & 278 & Guadalquivir & Ciudad Real & 5 \\
\hline $\mathrm{H} 4$ & Júcar & 626600 & 4440300 & 1156 & Cabriel & Cuenca & 2 \\
\hline H46 & Llobregat & 892440 & 4642224 & 325 & Coaner & Barcelona & 2 \\
\hline H47 & Llobregat & 915118 & 4628142 & 586 & Mura & Barcelona & 4 \\
\hline H48 & Llobregat & 903820 & 4687599 & 875 & Llobregat & Barcelona & 4 \\
\hline H49 & Llobregat & 903674 & 4671032 & 514 & Llobregat & Barcelona & 4 \\
\hline H5 & Tajo & 575800 & 4476500 & 936 & Escabas & Cuenca & 4 \\
\hline H50 & Llobregat & 913461 & 4664690 & 540 & Merlès & Barcelona & 2 \\
\hline H6 & Guadalquivir & 412404 & 4252640 & 459 & Robledillo & Ciudad Real & 3 \\
\hline H7 & Júcar & 643300 & 4355700 & 420 & Cabriel & Albacete & 4 \\
\hline $\mathrm{H} 8$ & Tajo & 339460 & 4391804 & 578 & Gévalo & Toledo & 3 \\
\hline H9 & Tajo & 550400 & 4508200 & 770 & Tajo & Guadalajara & 4 \\
\hline
\end{tabular}




\begin{tabular}{|c|c|c|c|c|c|c|c|}
\hline$\overline{\text { Code }}$ & Basin & ongitudeX_UTM & Latitude Y_UTM & Altitude m.a.s.l. & River/Stream & Province & Ecotype \\
\hline $\mathrm{R} 1$ & Laou & 286042 & 3910209 & 560 & Boumarouil & Tétouan & 1 \\
\hline $\mathrm{R} 10$ & Laou & 291725 & 3887981 & 360 & Laou & Chefchaouen & 4 \\
\hline $\mathrm{R} 11$ & Laou & 306906 & 3923220 & 20 & Laou & Chefchaouen & 5 \\
\hline $\mathrm{R} 12$ & Laou & 300313 & 3903040 & 340 & Talembote & Chefchaouen & 4 \\
\hline $\mathrm{R} 13$ & Laou & 302031 & 3901801 & 400 & Kelâa & Chefchaouen & 4 \\
\hline $\mathrm{R} 14$ & Martil & 271037 & 3911225 & 1220 & Taida & Larache & 1 \\
\hline $\mathrm{R} 15$ & Adelmane & 306148 & 3893546 & 1330 & Beni M'Hammed & Chefchaouen & 1 \\
\hline $\mathrm{R} 16$ & Adelmane & 304607 & 3893702 & 1530 & Madissouka & Chefchaouen & 4 \\
\hline $\mathrm{R} 17$ & Sebou & 305617 & 3891831 & 1500 & Guiness & Chefchaouen & 1 \\
\hline $\mathrm{R} 18$ & Sebou & 297030 & 3871776 & 1000 & Zebzar & Chefchaouen & 4 \\
\hline R19 & Sebou & 297030 & 3871776 & 1000 & Zebzar & Chefchaouen & 1 \\
\hline $\mathrm{R} 20$ & Martil & 279943 & 3925927 & 80 & Nakhla & Tétouan & 2 \\
\hline $\mathrm{R} 2$ & Laou & 301299 & 3887273 & 777 & Maggo & Chefchaouen & 4 \\
\hline R3 & Laou & 296827 & 3882350 & 680 & Ouara & Chefchaouen & 4 \\
\hline $\mathrm{R} 4$ & Laou & 296928 & 3877232 & 930 & Ouara & Chefchaouen & 4 \\
\hline R5 & Laou & 300818 & 3887868 & 905 & Maggo & Chefchaouen & 4 \\
\hline R6 & Laou & 290210 & 3897138 & 280 & Laou & Chefchaouen & 4 \\
\hline R7 & Laou & 293923 & 3905033 & 235 & Laou & Chefchaouen & 4 \\
\hline $\mathrm{R} 8$ & Laou & 293417 & 3893940 & 457 & Ras El Ma & Chefchaouen & 4 \\
\hline R9 & Laou & 301046 & 3913994 & 56 & Laou & Chefchaouen & 5 \\
\hline $\mathrm{T} 1$ & Segura & 593334 & 4250158 & 437 & Segura & Albacete & 4 \\
\hline $\mathrm{T} 2$ & Segura & 551125 & 4259314 & 940 & Mundo & Albacete & 4 \\
\hline $\mathrm{T} 3$ & Júcar & 555400 & 4289600 & 990 & Arquillo & Albacete & 4 \\
\hline $\mathrm{T} 4$ & Segura & 548400 & 4247100 & 840 & Tus & Albacete & 4 \\
\hline $\mathrm{T} 5$ & Guadiana Menor & or 522319 & 4195673 & 1220 & Castril & Granada & 2 \\
\hline T6 & Guadiana Menor & or 533413 & 4198285 & 1150 & Raigadas & Granada & 1 \\
\hline $\mathrm{T} 7$ & Guadiana Menor & or 528195 & 4193605 & 1110 & Buitre & Granada & 4 \\
\hline $\mathrm{T} 8$ & Guadiana Menor & or $\quad 528671$ & 4194040 & 1090 & Guardal & Granada & 4 \\
\hline T9 & Guadiana Menor & or 519225 & 4180285 & 780 & Castril & Granada & 4 \\
\hline
\end{tabular}

